\title{
Degradation of gallic acid and hydrolysable polyphenols is constitutively activated in the freshwater plant-associated bacterium Matsuebacter sp. FB25
}

\author{
Nicolai Müller ${ }^{1,2}$, Melanie Hempel ${ }^{1}$, Bodo Philipp ${ }^{2}$, Elisabeth M. Gross ${ }^{1, *}$ \\ ${ }^{1}$ Limnology, Department of Biology, University of Konstanz, PO Box 5560 M659, 78457 Konstanz, Germany \\ ${ }^{2}$ Microbiology, Department of Biology, University of Konstanz, PO Box 5560 M936, 78457 Konstanz, Germany
}

\begin{abstract}
Hydrolysable polyphenols are present in Myriophyllum spicatum L. at high concentrations of up to $25 \%$ of dry matter and are also excreted. Bacteria associated with the submerged macrophyte $M$. spicatum isolated from the surrounding water column and epiphytic biofilm were tested for their ability to degrade polyphenols. Several bacterial isolates were capable of growing with tannic acid as the sole carbon and energy source, among them Matsuebacter sp. FB25, Agrobacterium vitis EB26 and Pseudomonas sp. FB22. Cell suspensions of Matsuebacter sp. precultured on succinate were capable of degrading gallic acid, while those of $A$. vitis were not, indicating the constitutive presence of gallate-degrading enzymes in the former. When cells were precultured on gallic or tannic acid, cell suspensions of both strains exhibited an enhanced degradation rate of gallic acid. M. spicatum-derived hydrolysable polyphenols, which are comparable in structure to tannic acid, resulted in the same enhanced degradation rate of gallic acid or tellimagrandin II, the major $M$. spicatum polyphenol, by cell suspensions of Matsuebacter sp. FB25. The presence of polyphenoldegrading bacteria in the vicinity of $M$. spicatum explains the observed fast disappearance of tellimagrandin II and other hydrolysable polyphenols after excretion and has implications for allelochemical interference with competitors, herbivores and potential pathogenic microorganisms. The presence of Matsuebacter sp. and other polyphenol-degrading strains in such environments suggests a sufficiently strong effect of $M$. spicatum exudates to bring about selection in favour of highly specialised bacteria.
\end{abstract}

KEY WORDS: Hydrolysable polyphenol - Submerged macrophyte $\cdot$ Allelochemistry $\cdot$ Biofilm • Betaproteobacteria $\cdot$ Burkholderiales $\cdot$ Myriophyllum spicatum $\cdot$ Tannin

\section{INTRODUCTION}

The freshwater dicotyledonous plant Myriophyllum spicatum L. (Haloragaceae: Rosidae) produces and excretes bioactive hydrolysable polyphenols interfering with competitors and herbivores. On average, 7 to $10 \%$ of the plant dry mass $(\mathrm{dm})$ are polyphenols, among them tellimagrandin II ( $\beta$-1,2,3-tri-O-galloyl4,6-(S)-hexahydroxydiphenoyl-D-glucose). Apical shoots can even comprise more than $20 \%$ of polyphenols based on dry matter. Tellimagrandin II and other hydrolysable polyphenols inhibit algae and cyanobacteria by interference with extracellular alkaline phosphatase (Gross et al. 1996) or photosynthesis (Leu et al. 2002). Hydrolysable polyphenols cause a reduced growth of larvae of the aquatic moth Acentria ephemerella (Choi et al. 2002), and inhibit the growth of bacteria isolated from the gut of larvae (Walenciak et al. 2002). Exudates of $M$. spicatum also interfere with zooplankton (Linden \& Lehtiniemi 2005). Hydrolysable polyphenols are actively excreted by $M$. spicatum (Gross 2003), but the fate of individual 
polyphenols, e.g. tellimagrandin II, is difficult to assess and depends on multiple biotic (microbial degradation) and abiotic (oxidation, photodegradation) factors.

Since the allelochemical activity of Myriophyllum spicatum depends on the presence of tellimagrandin II and other hydrolysable polyphenols, a better knowledge of the role of microorganisms in the degradation of these polyphenols is needed. In polyphenols, the ester bonds between the sugar (often glucose) and gallic or ellagic acid are cleaved by tannase (tannin acyl hydrolase, EC 3.1.1.20), an enzyme frequently found in fungi or bacteria (Chowdhury et al. 2004, Li et al. 2006) and even in plants (Niehaus \& Gross 1997). The microbial degradation of gallic acid is possible by several distinct mechanisms ( $\mathrm{Li}$ et al. 2006). Under aerobic conditions, gallic acid can be degraded either (1) by following the $\beta$-ketoadipate pathway starting with a NADH-dependent reduction (Armstrong \& Patel 1992); or (2) by conversion into pyruvate and oxalacetate feeding into the citrate cycle, initiated by the action of gallate dioxygenase (Kasai et al. 2005, Nogales et al. 2005). The anaerobic degradation starts with gallate decarboxylase to yield pyrogallol, which is further degraded to acetate (Zeida et al. 1998). In aquatic systems, only a few strains (e.g. Pelobacter acidigallici from aquatic sediments: Schink et al. 2000) have been investigated for their capacity to degrade phenolic compounds, including gallic acid. Aerobic degradation is most plausible for epiphytic bacteria or bacteria living in the water surrounding $M$. spicatum.

The aims of the present study were (1) to investigate whether bacteria capable of growing with tannic acid or hydrolysable polyphenols can be isolated from the environment of Myriophyllum spicatum; (2) to then identify bacterial strains that are capable of growing solely on tannic or gallic acid; and (3) to investigate how these strains degrade tannic acid, gallic acid and tellimagrandin II.

\section{MATERIALS AND METHODS}

Origin of bacterial isolates and aquatic plants. Bacterial samples were collected from Myriophyllum spicatum stands in mesocosms at the Limnological Institute, University of Konstanz $\left(9.192^{\circ} \mathrm{N}, 47.694^{\circ} \mathrm{E}\right)$ during winter 2004/2005. The mesocosms are $2 \times 2 \times$ $1 \mathrm{~m}$ (depth) concrete basins, filled with a 7 to $10 \mathrm{~cm}$ layer of lake sediment, flushed constantly with water from Lake Constance, and planted with M. spicatum, which is wintergreen in these basins.

Pelagic bacteria were sampled in the vicinity of plant stands in the mesocosms. Epiphytic bacteria were retrieved from the upper $20 \mathrm{~cm}$ of plant shoots (measured from the apex) and placed directly in poly- propylene tubes filled with sterile water. Samples were transported in coolers to the laboratory and processed immediately. Pelagic bacteria were used immediately in enrichment cultures. Epiphytic bacteria were detached by ultrasonication at maximum output (Laboson 200 ultrasonic bath, Bender \& Hobein) from 3 to 20 Myriophylllum spicatum leaves in $2 \mathrm{ml}$ sodium pyrophosphate $\left(0.1 \mathrm{M} \mathrm{Na}_{4} \mathrm{P}_{2} \mathrm{O}_{7} \times 10 \mathrm{H}_{2} \mathrm{O}\right)$ for $2 \times 30 \mathrm{~s}$ with a $10 \mathrm{~s}$ break.

Isolation and enrichment of polyphenol-degrading bacteria. Water samples $(2 \mathrm{ml})$ or detached epiphytic bacteria ( $2 \mathrm{ml}$ ) were incubated under sterile conditions in $250 \mathrm{ml}$ Erlenmeyer flasks with $100 \mathrm{ml}$ modified Medium B (Hempel 2004: $5 \mathrm{mM} \mathrm{NH}_{4} \mathrm{Cl}, 0.5 \mathrm{mM}$ $\mathrm{MgSO}_{4} \times 7 \mathrm{H}_{2} \mathrm{O}, 14 \mathrm{mM} \mathrm{KCl}, 7.2 \mathrm{mM} \mathrm{NaCl}$; instead of $10 \mathrm{mM}$ HEPES, $10 \mathrm{mM}$ TRIS were used as buffer, medium adjusted to $\mathrm{pH} 7$ ). Directly before use, $1 \mathrm{ml}$ of 1000-fold concentrated trace element solution SL10 (Widdel et al. 1983), $0.1 \mathrm{ml}$ of $100 \mathrm{mM} \mathrm{Ca}_{2} \mathrm{Cl}$ and $0.3 \mathrm{ml}$ $0.15 \mathrm{mM} \mathrm{Na}^{+} / \mathrm{K}^{+}$-hydrogenphosphate solution ( $\mathrm{pH} \mathrm{7)}$ were added. Instead of $0.05 \%$ tryptone and $0.0005 \%$ yeast extract, we offered $294 \mu \mathrm{M}$ tannic acid as the sole source of carbon and energy. Cultures were incubated in the dark at $16^{\circ} \mathrm{C}$ and $200 \mathrm{rpm}$ on an orbital shaker and growth was followed by measuring optical density (OD) at $600 \mathrm{~nm}$. Growing cultures were diluted after 3 to $7 \mathrm{~d}$ in a series from $10^{-1}$ to $10^{-6}$ and plated on Medium B agar plates solidified with $1.5 \%$ agar, containing $0.05 \%$ tryptone and $0.0005 \%$ yeast extract, but no tannic acid. This change in carbon source was used to allow a faster growth of colonies. The plates were cultivated at $16^{\circ} \mathrm{C}$ in the dark. After $4 \mathrm{~d}$, colonies were picked and transferred to new plates. This procedure was repeated 3 times to single out colonies.

Each isolate was again tested for growth on tannic acid as sole carbon and energy source. Five microlitres of an actively growing culture of each strain were diluted in $295 \mu \mathrm{l}$ Medium B with $294 \mu \mathrm{M}$ tannic acid in 96-well microtitre plates. Growth was recorded in a microplate reader at $595 \mathrm{~nm}$ (Genios, Tecan). Only strains exhibiting significant growth $\left(\mathrm{OD}_{595}>0.09\right)$ were used further.

Identification of polyphenol-degrading strains. Selected strains were identified by DNA extraction, PCR amplification of the 16S rDNA gene, sequencing and BLAST searches using standard protocols. Growing isolates were harvested by centrifugation at $12000 \mathrm{rpm}(14800 \times \mathrm{g})$ and $4^{\circ} \mathrm{C}$ for $15 \mathrm{~min}$. The pellets were washed twice with sterile ultrapure water to break the cells by hypoosmotic shock. The final pellet was shock-frozen in liquid nitrogen and ultrasonicated at maximum output for $2 \times 30 \mathrm{~s}$ with a $10 \mathrm{~s}$ break. Cell debris was removed after resuspension of the pellet in $100 \mu \mathrm{l}$ sterile ultrapure water and centrifugation. The supernatant contained the DNA. 
One PCR reaction to amplify the 16S-rDNA gene contained $42.8 \mu \mathrm{l}$ PCR buffer (Taq buffer, Eppendorf), $5 \mu \mathrm{d}$ dNTPMix (500 mM, Eppendorf), $0.5 \mu l$ forward primer at $50 \mathrm{pmol} \mathrm{ul}^{-1}, 27 \mathrm{f} 5^{\prime}$ AGAGTTTGATCCTG

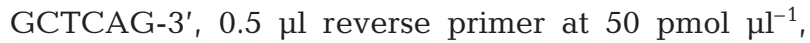
1492r 5'-TACGG(CT)TACC TTACGACTT-3', $1 \mu \mathrm{l}$ of DNA-template, and finally $1 \mathrm{U}$ Taq polymerase $(0.2 \mu \mathrm{l})$. We used a Thermocycler T-Gradient (Biometra) and the following protocol: (1) $3 \mathrm{~min}$ at $94^{\circ} \mathrm{C}_{i}$ (2) $30 \mathrm{~s}$ at $55^{\circ} \mathrm{C}_{i}(3) 1 \mathrm{~min}$ at $72^{\circ} \mathrm{C}_{i}(4) 30 \mathrm{~s}$ at $94^{\circ} \mathrm{C}_{i}(5) 30 \mathrm{~s}$ at $55^{\circ} \mathrm{C}_{i}$ (6) $1 \mathrm{~min}$ at $72^{\circ} \mathrm{C}_{i}$ repeat Steps 4 to $633 \times_{i}(7) 7 \mathrm{~min}$ at $72^{\circ} \mathrm{C}$. The PCR products were checked by loading $5 \mu \mathrm{l}$ sample with $1 \mu \mathrm{l} 6 \times$ loading buffer on $1 \%$ agarose gels in TAE buffer containing $40 \mathrm{mM}$ TRIS, $1 \mathrm{mM}$ EDTA and $20 \mathrm{mM}$ sodium acetate, $\mathrm{pH} 8$ adjusted with glacial acetic acid. Separation was performed at $130 \mathrm{~V}$ and $400 \mathrm{~mA}$ for $30 \mathrm{~min}$. The gels were stained for 30 to $40 \mathrm{~min}$ in $2.5 \mu \mathrm{M}$ ethidium bromide and DNA bands were identified under UV light with a BioDoc Analyzer (Biometra). Positive samples were purified using the QIAquick PCR Purification Kit (Qiagen) and sequenced by GATC (Konstanz). Sequences were compared with the NCBI database (www.ncbi.com) using the BLAST search tool.

Chemical analyses. HPLC calibration was performed by triplicate injection of concentration series of gallic acid (Sigma G7384) in the range 0 to $1 \mathrm{mM}$, or 0 to $0.2 \mathrm{mM}$ of purified tellimagrandin II (own source, 98\% HPLC-pure). Polyphenols were identified on a Jasco HPLC system using a Kromasil C18 column $(250 \times 4 \mathrm{~mm})$, Solvent A $(1 \%[\mathrm{v} / \mathrm{v}]$ acetic acid $)$ and $B$

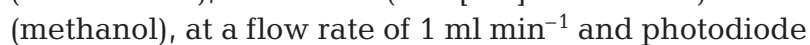
array detection set at the primary wavelengths 254 and $280 \mathrm{~nm}$. Gallic acid was analysed using isocratic conditions (8\% Solvent B and $92 \%$ Solvent A, $15 \mathrm{~min}$ ) and tellimagrandin II using a linear gradient of 0 to $15 \mathrm{~min}$ 8 to $60 \%$ Solvent B, 15 to 17 min 60 to $100 \%$ Solvent B, 17 to 20 min $100 \%$ Solvent B.

Tannic acid concentrations were determined photometrically by precipitation with bovine serum albumin and staining with $\mathrm{FeCl}_{3}$ (Hagerman \& Butler 1978). Besides quantification by HPLC, gallic acid was also quantified with the rhodanine method (Inoue \& Hagerman 1988) modified using citrate buffer instead of sulphuric acid (Sharma et al. 2000). A parallel analysis both photometrically and by HPLC confirmed that the 2 methods yield comparable results, with HPLC exhibiting slightly lower values $(\mathrm{c}[\mathrm{Hplc}]=0.88 \mathrm{c}[\mathrm{rho}-$ danin]; $\left.r^{2}=0.9995\right)$. Glucose was analysed on 500 -fold concentrated medium by HPLC following the method in Klebensberger et al. (2006).

In order to test the induction of tannic acid and gallic acid degradation in isolates by Myriophyllum spicatum polyphenols, we used crude extracts and a solid-phase extraction (SPE) fraction containing tellimagrandin II
(>80\%) isolated from apical shoots of M. spicatum. Plant material was extracted with aqueous acetone (1:1 [v/v]; $2 \times 2 \mathrm{~h}, 14^{\circ} \mathrm{C}$, constant stirring) followed by SPE on C18 cartridges (Phenomenex; 2 g sorbens) using a step-gradient elution with increasing methanol concentrations in water (Leu et al. 2002). The fraction containing tellimagrandin II eluted with $25 \%$ [v/v] methanol.

Growth experiments. Matsuebacter sp. FB25 was pregrown on Medium B with $294 \mu \mathrm{M}$ tannic acid. This strain was selected because of its high growth rate on tannic acid in first experiments. Cells were harvested and washed twice in Medium B without carbon source. Three different treatments were used: 3 Erlenmeyer flasks each containing $100 \mathrm{ml}$ of Medium B supplemented with either $294 \mu \mathrm{M}$ glucose, $294 \mu \mathrm{M}$ tannic acid or gallic acid were inoculated with cells at an initial $\mathrm{OD}_{600 \mathrm{~nm}}$ of 0.008 . Controls without bacteria were incubated in parallel. Culture conditions were the same as above. Samples were taken at regular intervals for $96 \mathrm{~h}$, and growth of the culture as well as substrate (glucose, gallic acid, tannic acid) concentrations of the medium were analysed.

Induction experiments. Three of the isolated strains were tested for their capability to degrade gallic acid or tannic acid with or without previous exposure to hydrolysable polyphenols. Four different treatments were set up. In each, cells were pregrown in Medium B supplemented with either $10 \mathrm{mM}$ succinate, $10 \mathrm{mM}$ succinate plus $294 \mu \mathrm{M}$ tannic acid, $294 \mu \mathrm{M}$ tannic acid or $1 \mathrm{mM}$ gallic acid. An initial $\mathrm{OD}_{600 \mathrm{~nm}}$ of 0.02 was used to shorten the lag phase. At the end of the exponential growth phase, cells of the different treatments were harvested by centrifugation, and adjusted to an $\mathrm{OD}_{600 \mathrm{~nm}}$ of ca. 1.0 in $5 \mathrm{ml}$ Medium B containing $1 \mathrm{mM}$ gallic acid in triplicates. Cell suspensions were stirred with $550 \mathrm{rpm}$ at $22^{\circ} \mathrm{C}$ on a magnetic stirrer. At $0,30,60$, 120 and $240 \mathrm{~min}$ each, $200 \mu \mathrm{l}$ were taken and trichloroacetic acid was added at a final concentration of $0.1 \mathrm{M}$ to stop enzyme reactions. After centrifugation $\left(13000 \mathrm{rpm}[16000 \times \mathrm{g}], 4^{\circ} \mathrm{C}, 5 \mathrm{~min}\right), 10 \mu \mathrm{l}$ each were analysed for gallic acid by HPLC.

We then tested whether Myriophyllum spicatum polyphenols also induce or accelerate the degradation of gallic acid and tellimagrandin II. Matsuebacter sp. FB25 was pregrown in Medium B containing either $75 \mu \mathrm{M}$ tannic acid $\left(\sim 125 \mathrm{mg} \mathrm{l}^{-1}\right)$ or crude plant extract (containing hydrolysable polyphenols measured as tannic acid equivalents of $125 \mathrm{mg} \mathrm{l}^{-1}$ ) using the same conditions as given above. Cells harvested at the end of the exponential growth phase were incubated with either $0.2 \mathrm{mM}$ tellimagrandin II or $1 \mathrm{mM}$ gallic acid in triplicates. We also performed controls testing the stability of gallic acid or tellimagrandin II in Medium B under the same environmental conditions $(\mathrm{pH}$, light, 
oxygen). The sampling protocols for gallic acid and tellimagrandin II were extended to 5 or $30 \mathrm{~h}$. Degradation rates were calculated based on protein content, derived from the $\mathrm{OD}_{660 \mathrm{~nm}}$ of cell suspensions used. One litre of a suspension of $1 \mathrm{OD}_{660 \mathrm{~nm}}$ was equivalent to $250 \mathrm{mg}$ dry mass, of which we estimated $50 \%$ as protein content.

\section{RESULTS}

\section{Isolation and enrichment of strains}

From the enrichment cultures on tannic acid, 96 isolates were obtained, 32 derived from the mesocosm water surrounding Myriophyllum spicatum (designated 'FB' for 'free bacteria' followed by strain number) and 64 from the plant biofilm (designated 'EB' for 'epiphytic bacteria', followed by strain number). Growth curves on $294 \mu \mathrm{M}$ tannic acid as sole carbon source were obtained with all isolates in microtitre plates. Most isolates reached an $\mathrm{OD}_{595 \mathrm{~nm}}$ of at least 0.05 after $160 \mathrm{~h}$. We selected the 15 best growing isolates, all exhibiting an $\mathrm{OD}_{595 \mathrm{~nm}}$ of $>0.09$, among these were 11 from the biofilm.

All 15 isolates were further characterised by sequencing the first $750 \mathrm{bp}$ of the 16S rDNA. Isolates FB19, FB24 and FB25 showed a 98 to $99 \%$ homology with Matsuebacter sp. 9 (AB024305) according to a BLAST search. FB22 exhibited $99 \%$ similarity to Pseudomonas sp. (e.g. AY599719), and all EB isolates (EB3, 4, $22,23,25,26,28,33,40,53,54)$ revealed several Agrobacterium vitis strains (e.g. AB247599) as closest relatives, with 96 to $99 \%$ similarity. Full sequences $(>1500 \mathrm{bp})$ of the $16 \mathrm{~S}$ rDNA of Strains FB22, FB25 and EB26 were obtained, confirming the abovementioned identifications with $>99 \%$ homology. These 3 isolates were used in further experiments. They are all rod-shaped bacteria. The 16S rDNA sequence of Matsuebacter sp. FB25 has been submitted to GenBank (EF110621). GenBank taxonomists indicate the change in genus name from 'Matsuebacter' to 'Mitsuaria'.

\section{Growth experiment}

Matsuebacter sp. FB25 exhibited the best growth on tannic acid and was therefore selected to study the details of tannic acid and gallic acid utilisation. Since tannic acid consists of multiple (usually 8 and up to 11) gallic acid residues esterified to glucose, we grew Matsuebacter sp. FB25 on either $294 \mu \mathrm{M}$ tannic acid or $294 \mu \mathrm{M}$ glucose for $90 \mathrm{~h}$ compared to sterile medium controls. Both controls also showed a slight increase in $\mathrm{OD}_{600 \mathrm{~nm}}$. In the case of tannic acid this most probably resulted from chemical reactions with Medium B constituents and subsequent precipitation. Matsuebacter sp. FB25 exhibited growth on both substrates, but grew faster and to a higher final density on tannic acid (Fig. 1A,B). We had offered an equimolar glucose concentration to test whether cells would use the sugar and not gallic acid after hydrolysis of tannic acid. The higher growth on tannic acid indicates that gallic acid is used as substrate. The uptake of glucose by Matsuebacter sp. FB25 could not be followed by HPLC because, even after concentration of the medium, glucose was below detection limit. Tannic acid declined in both control and the Matsuebacter sp. FB25 culture (Fig. 1C) to 181 and $105.5 \mu \mathrm{M}$ after $90 \mathrm{~h}$, respectively. The remaining

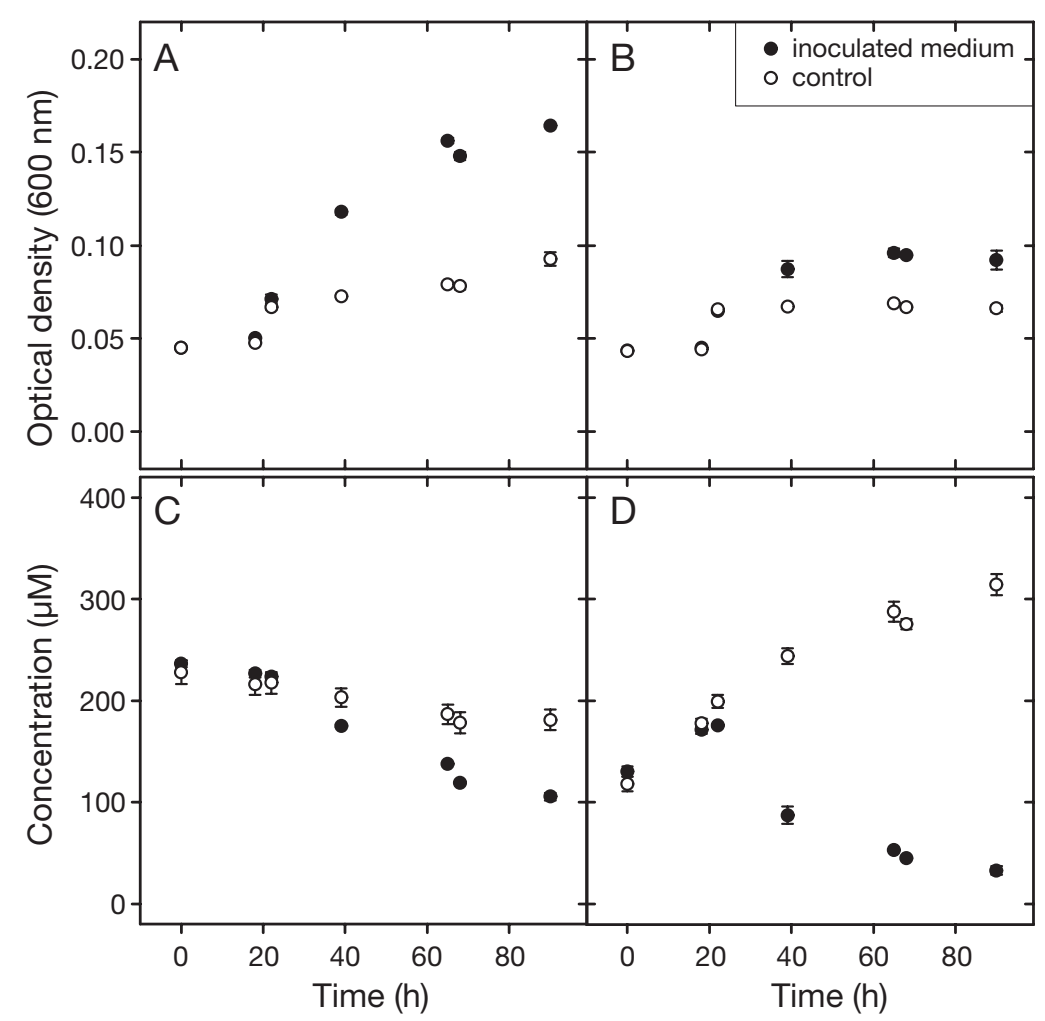

Fig. 1. Matsuebacter sp. Growth and substrate utilisation of Strain FB25 derived from water surrounding Myriophyllum spicatum in experimental mesocosms. (A) $\mathrm{OD}_{600 \mathrm{~nm}}$ of culture growing with $294 \mu \mathrm{M}$ tannic acid; (B) $\mathrm{OD}_{600 \mathrm{~nm}}$ of culture growing with $294 \mu \mathrm{M}$ glucose; (C) concentration of tannic acid in the culture with tannic acid as substrate; (D) concentration of gallic acid in the culture with tannic acid as substrate. Data are means $\pm \mathrm{SE}, \mathrm{n}=3$ (some error bars are smaller than symbol size) 
tannic acid concentrations in the Matsuebacter sp. FB25 culture differed significantly from the control after $39 \mathrm{~h}$ (2-way ANOVA and post-hoc Bonferroni $t$-test: $\mathrm{p}<0.04)$. Gallic acid in the control medium increased constantly from $t_{0 \mathrm{~h}}=118 \mu \mathrm{M}$ to $t_{90 \mathrm{~h}}=$ $314 \mu \mathrm{M}$, indicating spontaneous autolysis of tannic acid. In the Matsuebacter sp. FB25 culture, gallic acid increased for the first $22 \mathrm{~h}$ from 130 to $176 \mu \mathrm{M}$ and then declined to $33 \mu \mathrm{M}$ at $90 \mathrm{~h}$ (Fig. 1D), indicating an active degradation of this substrate.

\section{Induction of gallic acid degradation with or without precultivation on polyphenols}

In a second series of experiments, we initially cultured 3 isolates (Pseudomonas sp. FB22, Matsuebacter sp. FB25, Agrobacterium vitis EB26) on 4 different media with or without polyphenols to investigate whether the degradation of gallic acid is inducible. Pseudomonas sp. FB22 did not grow on tannic acid or gallic acid alone, thus the experiment was performed only with Matsuebacter sp. FB25 and Agrobacterium vitis EB26. Interestingly, Matsuebacter sp. FB25 could grow on $1 \mathrm{mM}$ but not on $2.35 \mathrm{mM}$ gallic acid (data not shown).

Cell suspensions of Matsuebactersp. FB25 were able to degrade gallic acid in all 4 treatments (Fig. 2A). The fastest degradation occurred when cells had been precultured on gallic acid (181.9 nmol gallic acid min $^{-1}$ $\mathrm{mg}^{-1}$ protein within the first $30 \mathrm{~min}$ ), followed by those grown on tannic acid (132.3 nmol gallic acid $\mathrm{min}^{-1}$ $\mathrm{mg}^{-1}$ protein) or succinate plus tannic acid (55.3 nmol gallic acid $\mathrm{min}^{-1} \mathrm{mg}^{-1}$ protein). Although at a much slower rate, even cells pregrown on succinate were able to degrade gallic acid (4.8 nmol gallic acid $\mathrm{min}^{-1}$ $\mathrm{mg}^{-1}$ protein).

Cell suspensions with Agrobacterium vitis EB26 exhibited a much slower degradation of gallic acid than Matsuebacter sp. FB25 in all 4 treatments (Fig. 2B). Cells pregrown on succinate or succinate plus tannic acid exhibited almost no degradation of gallic acid within $4 \mathrm{~h}$, while those induced with either tannic acid or gallic acid slowly degraded gallic acid (10.1 or $15.7 \mathrm{nmol}$ gallic acid $\mathrm{min}^{-1} \mathrm{mg}^{-1}$ protein within the first $30 \mathrm{~min}$, respectively).

\section{Induction of gallic acid or tellimagrandin II degradation in cells precultured on tannic acid or plant-extracted polyphenols}

First, we tested whether polyphenols extracted from Myriophyllum spicatum would also induce the degradation of gallic acid in Matsuebacter sp. FB25 compa-

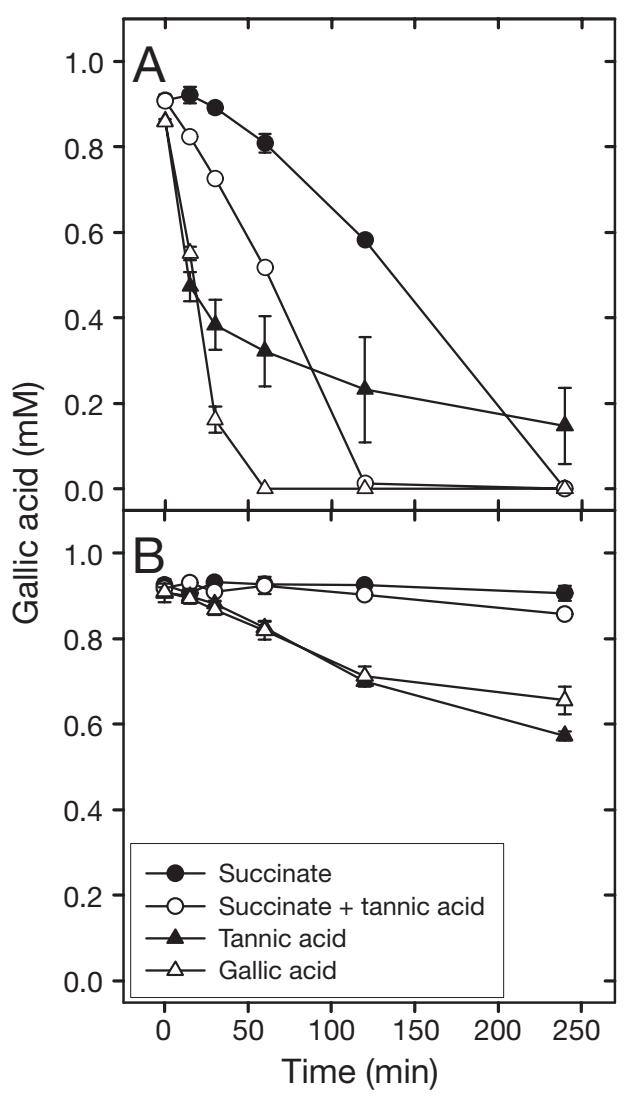

Fig. 2. Induction of gallate degradation in 2 bacterial strains isolated from Myriophyllum spicatum. (A) Matsuebacter sp. Strain FB25; (B) Agrobacterium vitis Strain EB26, derived from the epiphyton on Myriophyllum spicatum in experimental mesocosms. Data are means \pm SE $(n=3)$

rable to that observed with tannic acid. Cell suspensions pretreated with succinate plus either tannic acid or plant extract containing polyphenols at equivalent concentrations rapidly and completely degraded gallic acid within $5 \mathrm{~h}$. Slight, but significant differences in the initial degradation rate were observed (tannic acid or extract: 30.6 or $13.1 \mathrm{nmol}$ gallic acid $\mathrm{min}^{-1}$ $\mathrm{mg}^{-1}$ protein within the first $60 \mathrm{~min}$, respectively, $\mathrm{p}=$ 0.002), reaching maximum rates of 87.2 and $41.9 \mathrm{nmol}$ gallic acid $\mathrm{min}^{-1} \mathrm{mg}^{-1}$, respectively (Fig. 3A). We then investigated the degradation of tellimagrandin II by either gallic acid or extract induced cell suspensions. Tellimagrandin II was degraded in both treatments at rates of 0.8 to $4.5 \mathrm{nmol}$ tellimagrandin II $\mathrm{min}^{-1} \mathrm{mg}^{-1}$ protein by induced cells (Fig. 3B). Without bacterial cells, tellimagrandin II declined at a rate of only

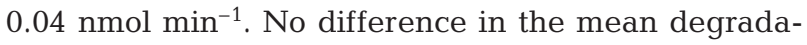
tion rate of either gallic acid or tellimagrandin II between tannic acid or plant extract induced cells was observed (paired $t$-tests: gallic acid: $\mathrm{p}=0.760$; tellimagrandin II: $\mathrm{p}=0.743$ ). 

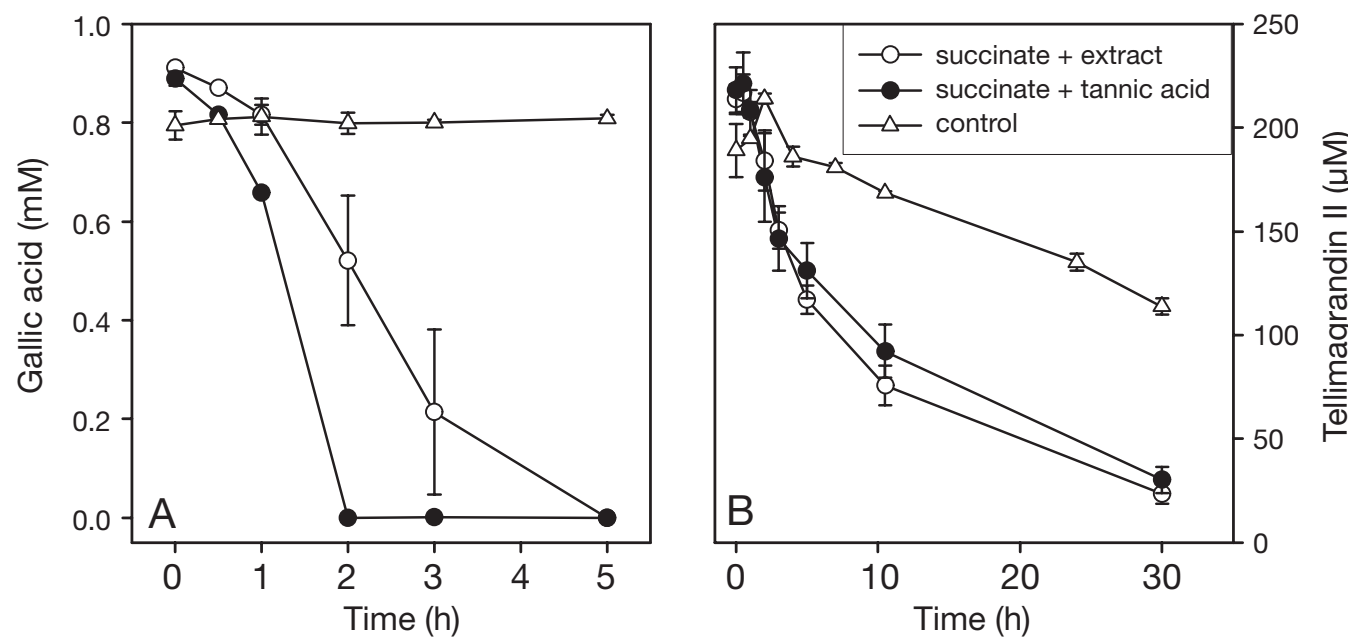

Fig. 3. Matsuebacter sp. Strain FB25. Cell suspension experiments. Cell suspensions offered (A) $1 \mathrm{mM}$ gallic acid and (B) $0.2 \mathrm{mM}$ tellimagrandin II. Data are means $\pm \mathrm{SE}, \mathrm{n}=3$ (some error bars are smaller than symbol size)

\section{DISCUSSION}

Several bacterial strains isolated via enrichment cultures on tannic acid from the environment of the polyphenol-producing submerged macrophyte Myriophyllum spicatum were able to degrade tannic acid, gallic acid or plant-derived tellimagrandin II, and could even use these substrates as sole carbon and energy source. To our knowledge, this is the first study investigating the role of bacteria in degrading Myriophyllum-derived polyphenols. Previous studies of Myriophyllum-associated bacteria focused on potential pathogens useful for the biological control of $M$. spicatum (Chand et al. 1992) or on rhizosphere bacteria involved in nitrogen metabolism (Blotnick et al. 1980). So far, the majority of studies focusing on tannin-degrading bacteria are either from environments exposed to industrial tannery waste (Chowdhury et al. 2004, Franco et al. 2005) or from investigations of intestinal bacteria in tannin-feeding invertebrates and vertebrates (Goel et al. 2005, Smith et al. 2005), while little evidence exists for such specialised bacteria in natural waters, most of them from anaerobic environments (Mahadevan \& Muthukumar 1980, Schink et al. 2000). In contrast to other major submerged aquatic angiosperms, $M$. spicatum produces and releases high concentrations of hydrolysable polyphenols (Smolders et al. 2000, Choi et al. 2002, Gross 2003). Indirect evidence already suggested a limited persistence of released polyphenols in water (Gross \& Sütfeld 1994, Nakai et al. 1999), and herein we provide evidence for the bacterial degradation of these allelochemicals.

The 3 major strains isolated and identified in our study (Pseudomonas sp. FB22, Agrobacterium vitis EB26 and Matsuebacter sp. FB25) have not directly been associated with tannin degradation so far. Many Pseudomonas strains are able to degrade a wide range of aromatic hydrocarbons, yet our isolate Pseudomonas sp. FB22 did not grow as pure culture only on tannic or gallic acid, suggesting that this strain used other carbon sources. Eleven isolates derived directly from the biofilm on Myriophyllum spicatum were identified as strains of the Gram-negative Alphaproteobacteria A. vitis. Usually $A$. vitis strains are found on grapevines, where they may prove serious pathogens. In that environment, they may come in contact with and be able to degrade grapevine polyphenols, comparable to the polyphenol-degrading capacity of the strain A. vitis EB26 we isolated from the biofilm on M. spicatum.

Matsuebacter sp. FB25 was the most interesting among our tannin-degrading isolates since it was capable of using gallic acid without prior induction. Two of our other isolates (FB19, FB24) were also affiliated to Matsuebacter. Other relatives to Matsuebacter sp. FB25 are Herbaspirillum spp., e.g. H. chlorophenolicum CT2 (AY702478), which has been isolated from the rhizosphere of emergent macrophytes grown in a tannery effluent exposed wetland (Franco et al. 2005).

Matsuebacter sp. FB25 seems to be a specialist for hydrolysable polyphenols; this strain grew even faster on tannic acid than on glucose. When grown with tannic acid, a lag time of approx. $40 \mathrm{~h}$ was observed, suggesting that either tannase needed for the hydrolytic cleavage had to be induced or cells could only grow when sufficient tannic acid underwent autolysis to yield free gallic acid. A direct comparison of degradation rates of gallic acid between Matsuebacter sp. FB25 and Agrobacterium vitis EB26 clearly shows the faster adaptation of the former when exposed to gallic or tannic acid. Cell suspensions of $A$. 
vitis EB26 precultured on succinate or even succinate plus tannic acid did not exhibit a significant degradation of gallic acid within $4 \mathrm{~h}$, and even when precultured on tannic or gallic acid, only about 30 to $40 \%$ of the substrate (gallic acid) was degraded during that time. In contrast, cell suspensions of Matsuebacter sp. FB25 degraded gallic acid at higher rates and, in most cases, completely used the offered substrate, although cells incubated earlier with succinate exhibited somewhat slower initial degradation rates. Tellimagrandin II from Myriophyllum spicatum was also degraded by Matsuebacter sp. FB25, but at a slower rate. It might be that the ellagic acid (a dilactone of gallic acid) derived from the hexahydroxydiphenoic moiety in tellimagrandin II interferes with the degradation of this hydrolysable polyphenol and gallic acid. Ellagic acid may have antimicrobial activity, as shown for extracted phenolic compounds from the floating macrophyte Nuphar variegatum (Nishizawa et al. 1990). Ellagic acid and tannic acid had an antagonistic effect on AHL-dependent quorum-sensing systems in Escherichia coli MT102 (pSB403) (Huber et al. 2003).

The gallic acid degradation in both Matsuebacter sp. FB25 and Agrobacterium vitis EB26 occurs under oxic conditions, but we do not know yet which pathway is used. Most probably gallate dioxygenases are involved, comparably to gallate-degrading enzymes found in Pseudomonas putida KT2440 or Sphingomonas paucimobilis SYK-6 (Kasai et al. 2005, Nogales et al. 2005). Further biochemical studies are needed to clarify the degradation pathway and intermediate metabolites.

At present, we cannot say how abundant tannindegrading strains are in the biofilm or water surrounding Myriophyllum spicatum. It is quite likely that other, yet unidentified and uncultured, strains with the same metabolic capacity to degrade hydrolysable polyphenols are present. In a parallel study of epiphytic bacteria on submerged macrophytes, we isolated a strain closely related to Pantoea agglomerans from $M$. spicatum. This strain (formerly named Enterobacter agglomerans) is known to possess tannase and gallic acid decarboxylase (Zeida et al. 1998).

The presence of tannin-degrading bacteria as epiphytes of tannin-producing plants might even be beneficial to other, non-adapted bacteria. The inhibition of bacteria by tannins is mainly based on their complexation with essential polymers and minerals (Scalbert 1991, Smith et al. 2005), thus affecting cellbound or extracellular proteins or the uptake of nutrients. Tannin-tolerant bacteria, in contrast, have evolved different mechanisms to overcome these limitations (Smith et al. 2005), e.g., the modification or degradation of tannins, the dissociation of tanninsubstrate complexes, tannin inactivation by high-affinity binders, membrane modifications or repair, and metal ion sequestration. Epiphytic microorganisms are 3-dimensionally enmeshed with hydrated mucopolysaccharide materials excreted by epiphytic bacteria and algae. Such a matrix might bind Myriophyllum spicatum-released polyphenols and render them less toxic to epiphytic bacteria (Ervin \& Wetzel 2003).

Bacteria often influence allelopathically active compounds. Juglone from walnut trees is only active after hydrolysis by soil bacteria. Several phenolic compounds released by Polygonella myriophylla, an allelopathically active shrub of the Florida sand pine scrub community, undergo rapid degradation or conversion in non-sterile soil compared to sterile conditions (Weidenhamer \& Romeo 2004). Whether the presence of bacteria diminishes the allelopathic activity is difficult to say, because this depends on the rate of production and release of active compounds and the rate of conversion/degradation. Similarly, the degradation of polyphenolic allelochemicals by associated microorganisms has important implications for the chemical ecology of Myriophyllum spicatum. First, exuded polyphenols have only a limited half-life and do not accumulate. This would be expected, since a constant rise in such inhibitory compounds would not allow the plant to regulate the active concentration in its vicinity. However, if exuded polyphenols are degraded too fast, their deleterious effect on competing phytoplankton or epiphytic algae and cyanobacteria should decline. In short-term experiments, tellimagrandin II is detectable in axenic (bacteria-free) cultures (Gross \& Sütfeld 1994), and other compounds, possibly oxidation products, increase over time. When non-axenic plants are incubated in water, tellimagrandin II and other hydrolysable polyphenols decline even faster, suggesting microbial break-down. Bacterial degradation together with photochemical conversion probably accounts for the failure to detect tellimagrandin II in exudates of field M. spicatum (Glomski et al. 2002). Nevertheless, M. spicatum exudates are inhibitory to cyanobacteria and algae, but the exposure to such allelopathically active compounds has to be (semi)continuous (Nakai et al. 1999).

Acknowledgements. We acknowledge the technical assistance of C. Feldbaum and helpful discussions with H. P. Grossart and B. Schink. This project was supported by DFG German Science foundation in project CRC454, A2 to E.M.G. and B9 to B.P., and by the University of Konstanz, AFF to E.M.G. and B.P.

\section{LITERATURE CITED}

Armstrong S, Patel TR (1992) Fortuitous resorcinol metabolism by a phloroglucinol-induced Rhodococcus sp. Bpg-8. J Basic Microbiol 32:363-367

Blotnick JR, Rho J, Gunner HB (1980) Ecological characteris- 
tics of the rhizosphere microflora of Myriophyllum heterophyllum. J Environ Qual 9:207-210

Chand T, Harris RF, Andrews JH (1992) Enumeration and characterization of bacterial colonists of a submersed aquatic plant, Eurasian watermilfoil (Myriophyllum spicatum L.). Appl Environ Microbiol 58:3374-3379

Choi C, Bareiss C, Walenciak O, Gross EM (2002) Impact of polyphenols on growth of the aquatic herbivore Acentria ephemerella. J Chem Ecol 28:2245-2256

Chowdhury SP, Khanna S, Verma SC, Tripathi AK (2004) Molecular diversity of tannic acid degrading bacteria isolated from tannery soil. J Appl Microbiol 97:1210-1219

Ervin GN, Wetzel RG (2003) An ecological perspective of allelochemical interference in land-water interface communities. Plant Soil 256:13-28

Franco AR, Calheiros CSC, Pacheco CC, De Marco P, Manaia CM, Castro PML (2005) Isolation and characterization of polymeric galloyl-ester-degrading bacteria from a tannery discharge place. Microb Ecol 50:550-556

Glomski LAM, Wood KV, Nicholson RL, Lembi CA (2002) The search for exudates from Eurasian watermilfoil and Hydrilla. J Aquat Plant Manag 40:17-22

Goel G, Puniya AK, Aguilar CN, Singh K (2005) Interaction of gut microflora with tannins in feeds. Naturwissenschaften 92:497-503

Gross EM (2003) Differential response of tellimagrandin II and total bioactive hydrolysable tannins in an aquatic angiosperm to changes in light and nitrogen. Oikos 103: 497-504

Gross EM, Sütfeld R (1994) Polyphenols with algicidal activity in the submerged macrophyte Myriophyllum spicatum L. Acta Hortic 381:710-716

Gross EM, Meyer H, Schilling G (1996) Release and ecological impact of algicidal hydrolysable polyphenols in Myriophyllum spicatum. Phytochemistry 41:133-138

Hagerman AE, Butler, LG (1978) Protein precipitation method for quantitative determination of tannins. J Agric Food Chem 26:809-812

Hempel M (2004) Untersuchungen zur Bedeutung AHLvermittelter Zell-Zell Kommunikation heterotropher Bakterien im Bodenseelitoral. Diplomarbeit, Universitaet Konstanz

Huber B, Eberl L, Feucht W, Polster J (2003) Influence of polyphenols on bacterial biofilm formation and quorum sensing. Z Naturforsch Sect C J Biosci 58:879-884

Inoue KH, Hagerman AE (1988) Determination of gallotannin with rhodanine. Anal Biochem 169:363-369

Kasai D, Masai E, Miyauchi K, Katayama Y, Fukuda M (2005) Characterization of the gallate dioxygenase gene: three distinct ring cleavage dioxygenases are involved in syringate degradation by Sphingomonas paucimobilis SYK-6. J Bacteriol 187:5067-5074

Klebensberger J, Rui O, Fritz E, Schink B, Philipp B (2006) Cell aggregation of Pseudomonas aeruginosa strain PAO1 as an energy-dependent stress response during growth with sodium dodecyl sulfate. Arch Microbiol 185:417-427

Editorial responsibility: Ruben Sommaruga, Innsbruck, Austria
Leu E, Krieger-Liszkay A, Goussias C, Gross EM (2002) Polyphenolic allelochemicals from the aquatic angiosperm Myriophyllum spicatum L. inhibit photosystem II. Plant Physiol (Rockv) 130:2011-2018

Li MS, Yao K, He Q, Jia DY (2006) Biodegradation of gallotannins and ellagitannins. J Basic Microbiol 46:68-84

Linden E, Lehtiniemi M (2005) The lethal and sublethal effects of the aquatic macrophyte Myriophyllum spicatum on Baltic littoral planktivores. Limnol Oceanogr 50:405-411

Mahadevan A, Muthukumar G (1980) Aquatic microbiology with reference to tannin degradation. Hydrobiologia 72: 73-79

Nakai S, Inoue Y, Hosomi M, Murakami A (1999) Growth inhibition of blue-green algae by allelopathic effects of macrophytes. Water Sci Technol 39:47-53

Niehaus JU, Gross GG (1997) A gallotannin degrading esterase from leaves of pedunculate oak. Phytochemistry 45:1555-1560

Nishizawa K, Nakata I, Kishida A, Ayer WA (1990) Some biologically active tannins of Nuphar variegatum. Phytochemistry 29:2491-2494

Nogales J, Canales A, Jimenez-Barbero J, Garcia JL, Diaz E (2005) Molecular characterization of the gallate dioxygenase from Pseudomonas putida KT2440 - the prototype of a new subgroup of extradiol dioxygenases. J Biol Chem 280:35382-35390

Scalbert A (1991) Antimicrobial properties of tannins. Phytochemistry 30:3875-3883

Schink B, Philipp B, Muller J (2000) Anaerobic degradation of phenolic compounds. Naturwissenschaften 87:12-23

Sharma S, Bhat TK, Dawra RK (2000) A spectrophotometric method for assay of tannase using rhodanine. Anal Biochem 279:85-89

Smith AH, Zoetendal E, Mackie RI (2005) Bacterial mechanisms to overcome inhibitory effects of dietary tannins. Microb Ecol 50:197-205

Smolders AJP, Vergeer LHT, van der Velde G, Roelofs JGM (2000) Phenolic contents of submerged, emergent and floating leaves of aquatic and semi-aquatic macrophyte species: why do they differ? Oikos 91:307-310

Walenciak O, Zwisler W, Gross EM (2002) Influence of Myriophyllum spicatum-derived tannins on gut microbiota of its herbivore Acentria ephemerella. J Chem Ecol 28: 2045-2056

Weidenhamer JD, Romeo JT (2004) Allelochemicals of Polygonella myriophylla: chemistry and soil degradation. J Chem Ecol 30:1067-1082

Widdel F, Kohring GW, Mayer F (1983) Studies in dissimilatory sulfate-reducing bacteria that decompose fatty acids. Characterisation of filamentous gliding Desulfonema limicola gen. nov. sp. nov., and Desulfonema magnum sp. nov. Arch Microbiol 134:286-294

Zeida M, Wieser M, Yoshida T, Sugio T, Nagasawa T (1998) Purification and characterization of gallic acid decarboxylase from Pantoea agglomerans T71. Appl Environ Microbiol 64:4743-4747

Submitted: December 4, 2006; Accepted: January 30, 2007 Proofs received from author(s): March 1, 2007 